\title{
Validation of Resilience Scale(CD-RISC) in elite athletes through a structural equation model Validación de la Escala de Resiliencia (CD-RISC) en deportistas de élite a través de un modelo de ecuaciones estructurales
}

\author{
Marta Olmo Extremera, Eva Olmedo Moreno, MarCepero González, Felix Zurita Ortega, Rosario Padial Ruz \\ Universidad de Granada
}

\begin{abstract}
Summary. Resilience is a psychological characteristic that encourages positive adaptation in the face of adversity (Connor \& Davidson, 2003; Grotberg, 2001; Wagnild \& Young, 1990). It has seldom been studied within the field of sports but, in the last years the studies began to be more common (Fletcher \& Sarkar, 2012; Galli \& Vealey, 2012; García- Secades et al., 2015). This work has as purposes, to adapt the resilience scale (CDRISC) for the sport field, to confirm its psychometrics properties and to analyses, validation its internal consistency in a population of elite athletes in different sports. The scale was administered to a sample of 287 athletes, $76.7 \%$ male and $23.3 \%$ female, determined by four levels of competition; 21.5\% professionals, $21.3 \%$ semi-professionals, $43.9 \%$ amateur and $9.8 \%$ enthusiastic. It was an analysis based on structural equations modelling (SEM) encompassed within confirmatory factor analysis (CFA) and its internal consistency (Cronbach's Alpha). The results verified that the modelling of structural equation, the model for measuring the questionnaire and the covariant structure of the responses obtained have a good fit. Thus, the CD-RISC scale has shown itself to be a reliable and valid tool for measuring the resilience of elite athletes and it can also be used to measure psychological parameters related to the field of sports.
\end{abstract}

Keywords: Resilience, Sport, Adversity, Optimist, Validation.

Resumen. La resiliencia es una característica psicológica que permite una adaptación positiva ante la adversidad (Connor \& Davidson, 2003; Grotberg, 2001; Wagnild \& Young, 1990). Sus estudios en el campo deportivo no han sido muy numerosos, aunque en los últimos años esta tomando fuerza en esta area (Fletcher \& Sarkar, 2012; Galli \& Vealey, 2012; García- Secades et al., 2015). El trabajo que se presenta tiene como objetivos adaptar al campo deportivo la escala de resiliencia (CD-RISC), confirmar sus propiedades psicométricas, analizar y validar su consistencia interna en una población de atletas de élite en diferentes deportes. La escala fue aplicada a una muestra de 287 atletas, 76,7\% hombres y 23,3\% mujeres diferenciados por cuatro niveles de competición; 21,5\% profesionales, 21,3\% semi-profesionales, 43,9\% amateur y 9,8\% aficionados. Se utilizó un análisis basado en un modelo de ecuaciones estructurales (SEM) circunscritos a un análisis de confirmación de los factores (CFA) y su consistencia interna (Alfa de Cronbach). Los resultados verificaron que el modelo de ecuaciones estructurales, la mediación del cuestionario y la estructura covariante de las respuestas obtenidas tienen un buen ajuste. Por tanto, la escala CD-RISC ha demostrado ser una herramienta confiable y válida para medir la capacidad de resiliencia de los deportista de élite pudiendo ser utilizada para medir los parámetros psicológicos relacionados con el campo deportivo.

Palabras clave: Resiliencia, Deporte, Adversidad, Optimismo, Validación.

\section{Theoretical Framework}

The 21st century is producing new challenges in sports, considering them as an object of analysis not exclusively from the point of view of specialised physiology. In addition, there has been an introduction with greater relevance to study techniques that lean towards the field of psychology. As a result, sport has become an object of research from this perspective, with numerous and varied studies in specific areas such as sports injuries, stress, anxiety, mental resistance, resilience, etc. (Almeida, Luciano, Lameiras, Buceta, 2014; Cardoso \& Sacomori, 2014; Chacón, Castro- Sánchez, Espejo- Garcés \& Zurita, 2016; Da Costa \& Ferreira, 2013; Galli \& González, 2014; Hosseini \& Besharat, 2010; Ruiz, De la Vega, Poveda Rosado \& Serpa, 2012; Ruiz- Barquín, Del Campo \& De la Vega, 2015; Sarkar \& Fletcher, 2014).

In view of this situation we find that resilience is a concept that is frequently becoming more important in sporting activity. It can be understood as a factor of positive development for people who have lived through situations of risk throughout their lives or at a specific time in their lives (Garcia- Secades et al., 2015; Luthar, Cicchetti \& Becker, 2000; Machida, Irwin\& Feltz, 2013; Masten \& O’Dougherty Wright, 2010; Reche \& Ortín, 2014).

Despite its first studies in the 1980s, resilience has recently started to be considered as an effective response model before adversities in different groups: adolescents, (Xiao, Joseph, Winnie, Jianxin, Wacy, 2011), senior citizens (Lamond, Depp, Allison, Langer, Reichstadt, 2009), immigrants (Aroian, Norris, 2000), entrepreneurs (Manzano- García \& Ayala, 2013) and educators (Forés \& Grané, 2012).

Fecha recepción: 09-05-16. Fecha de aceptación: 23-11-16 Marta Olmo Extremera kukuxumusutxu@gmail.com
Within the field of sports, resilience appears in different studies addressing resilient factors and other psychological aspects that influence the personal and professional life of an athlete (Cevada et al., 2012; Gucciardi, Jackson, Coulter \& Mallett, 2011; Hosseini \& Besharat, 2010; Morgan, Fletcher, Sarkar, 2013).

The life of an athlete draws together challenges, such as different categories of competition (Ivarsson, Johnson \& Podlog, 2013; Petrie, Deiters \& Harrison, 2013), which cause pressure and stress to his or her physical and mental state.

Every year a large number of athletes suffer from injuries regardless of their competitive level (Trip, Stanish, Ebel-Lam, Brewer \& Birchard, 2011), to be submission a big pressure in competition moments, high- performance training, stress trigged by good sport results, scary to sporting failure (Garcia et al., 2015; Castro, Chacón, Zurita, Espejo, 2016; Iriarte, 1999; Yi, Smith \& Vitaliano, 2005)

This stems from moments of uncertainty, generating emotional discomfort and moods that influence the professional and personal development of athletes, even causing them to abandon their careers. Therefore, there is a need for sports intervention programmes orientated towards conditioning athletes' moods, encouraging positive emotional responses in the face of adversities which help to improve their levels of motivation and self-confidence, as put forward by Olmedilla \& Garcia-Mas (2009).

In turn, the model of Wiese-Bjornstal, Smith, Shaffer \& Morrey (1998) asserts that athletes obtain positive aspects from their adverse experiences; positive change in their selfperspective, resilience and self-efficacy.

Resilience has been measured in other fields of work via different descriptive and quantitative methods. As a demonstration, the investigation focuses on the ConnorDavidson CD-RISC resilience scale (2003). This instrument allows a simple and complete evaluation of resilience, alluding 
to personal resources and positive qualities that permit appropriate responses in the face of adversity. This scale focuses on the personal resources and qualities considered appropriate for positive adaptation to adversity. A model of 25 items composed of five factors arises from the analysis of the data obtained from clinical populations, comprising: personal competence (high standards and tenacity), trust in instincts (tolerance of negative effects), strengthening of the effects of stress (positive acceptance of change, dependable relationships), locus of control and spiritual influences.

This measuing instrument has been applied in the clinical field (Anderson \& Bang, 2012; Markovitz, Peters, Schrooten, Schouten, 2014; Solano \& Neto, 2012) and in general populations (Jeste et al., 2013; Otto, Howerter, Bell, Jackson, 2010) and sport (Fletcher \& Sarker, 2012; Galli \& Vealey, 2008; Gucciardi, Jackson, Coulter, Mallett, 2011; Romero, 2015; Ruiz, De la Vega, Poveda, Rosado \& Serpa, 2012; Wagnield \& Young, 1993).

From the very beginning the psychometric results from the CD-RISC factorial structure confirmed this 25 items and their five factors (Burns \& Anstey, 2010).

Despite the growing interest in the use of CD-RISC in research and its recuperative capacity, no study has examined its psychometric properties on the sports population. Roughly speaking, the validity of the CD-RISC in contexts that have not previously been studied implies in the elastic qualities it measures. Specifically referring to the field of sports, the availability of a psychometric measure would give researchers the means to research processes or mechanisms where athletes live through adverse situations that generate optimistic responses to them (Gucciardi et al., 2011).

Meanwhile, for its part, is a guarantee of the quality of a test. It makes reference to the level in which empirical evidence and theory support the interpretation of the grading of a specific test. Despite there are different types of validity, we had used the version scale of adaptation Connor- Davidson (CD-RISC) translate to the Spanish by Bobes et al., (2008). In this study we have focused on the construct validity: analysis of the internal structure of the test. This is going to allow us to consider the dimensions of the construct in question. The mathematical procedure used to obtain its factorial analysis, from which we will be able to determine the level at which the empirical evidence and the dimensional structure coincide with the structure postulated by its authors, Connor\& Davidson (2003).

\section{Method}

For this study, it has been developed an analysis based on structural equations modelling (SEM), encompassed within confirmatory factor analysis (CFA), which permits contrasting with a model constructed «a priori» wherein the total group of relationships between the elements that configure it are established. Thus the researcher will have greater flexibility when establishing hypotheses on the structure of the construct (Bentler, 2007). It is, therefore, a type of inferential analysis utilising multivariate regression to relate response patterns to a group of latent factors that are not directly observed but, according to substantive theory, exist in continuous dimensions in people who are evaluated (Rizopoulos, 2006). Therefore, this structural equation model provides solid technical procedures and criteria for the validation of measuring models under two conditions (González-Montesinos \& Backhoff, 2010):

- Conditional independence, understood as a combination of latent factors (for example, aptitudes, attitudes or perceptions), that influences a group of observed variables, measured via the reactive ones which make up a scale, in such a way that the responses to these reactives are independent between themselves, but conditioned by the latent variable that determines them.

- The latent factors can be quantified via a structure of dimensions, which is based on a substantive theory that postulates the existence of psychological constructs that exercise a casual influence over the responses of people in a reactive group.

\section{Design and Participants}

In this descriptive and exploratory investigation a total of 287 athletes ( $76.7 \%$ male and $23.3 \%$ female) took part, belonging to four competitive levels (25.1\% professional, $21.3 \%$ semiprofessional, $43.9 \%$ amateur, $9.8 \%$ enthusiast) with a representation of 14 clubs. Out of this participants there is a predominance of footballers, making up $64 \%$ of the total number, with $35.5 \%$ comprising of athletes from minority sports (see table 1). On the whole they formed part of teams from Granada, Jaén and Madrid.

\begin{tabular}{|c|c|c|c|c|}
\hline \multirow[b]{2}{*}{ Sport Category } & \multicolumn{2}{|c|}{ Gender $(M=23.05 ; 7.560)$} & \multirow[b]{2}{*}{ Frequency } & \multirow[b]{2}{*}{ Total } \\
\hline & $\begin{array}{c}\text { Male(M=23.29; } \mathrm{DE}= \\
7.77)\end{array}$ & $\begin{array}{c}\text { Female }(\mathrm{M}=22.28 ; \\
\mathrm{DE}=6.81)\end{array}$ & & \\
\hline Football & 167 & 18 & 185 & $64.5 \%$ \\
\hline Handball & 16 & 0 & 16 & $5.6 \%$ \\
\hline Cycling & 9 & 1 & 10 & $3.5 \%$ \\
\hline Gymnastics - & 1 & 9 & 10 & $3.5 \%$ \\
\hline $\begin{array}{l}\text { Acrobatics } \\
\text { Hockey }\end{array}$ & 0 & 28 & 28 & $9.8 \%$ \\
\hline Trail-Running & 0 & 4 & 4 & $1.4 \%$ \\
\hline Swimming & 3 & 3 & 6 & $2.1 \%$ \\
\hline Mountaineering & 0 & 2 & 2 & $0.7 \%$ \\
\hline Athletics & 4 & 4 & 8 & $2.8 \%$ \\
\hline Triathlon & 0 & 3 & 3 & $1.0 \%$ \\
\hline Ski & 3 & 8 & 11 & $3.8 \%$ \\
\hline Snowboarding & 1 & 3 & 4 & $1.4 \%$ \\
\hline
\end{tabular}

The sample was selected via probabilistic sampling by conglomerates and on purpose because we had some challenges to get an open aptitude by the sport clubs. Out of the 14 participating clubs, football represents the largest part of the participation of the sample.These are divided into three categories according to competition level: first division 54\%, second division $30 \%$ and youth $62 \%$.

Furthermore, it has been interested on selecting 12 minority sports clubs from the region of the main sample, which corresponds to $35.5 \%$ of the total number of participants. Thus, we are attempting to validate the CD-RISC instrument both with majority and minority sports.

\section{Instruments}

In this study we have applied the Connor-Davidson CDRISC resilience scale (2003) orientated towards elite athletes from different sports.

It is a self-applied tool of 25 items, with a Likert type response system from 1 «completely disagree» to 4 «completely agree», which measures the ability to face adversity. In turn, it is a multidimensional instrument comprised of five resilience factors: locus of control and commitment, challenge of behaviour orientated towards action and self-efficacy, resistance to discomfort, optimism, and adaptations to stressful and spiritual situations.

A preliminary study on the psychometric properties of the CD-RISC in a general population and clinical psychological patients supported its internal consistency, reliability and convergent and divergent validity (Connor \& Davidson, 2003).

However our target population requires a prior adaptation and validation as these validation tests do not exist for this cultural group and subjects.

\section{Procedure}

To gather the information different stages have been 
implemented which have allowed us to select the sample as well as the instrument used and its validation.

1. The initial stage was dedicated to the selection of the population, where twelve sports were selected with different characteristics such as groups and individuals, or different levels of competition. Participation was higher in football, hockey and handball and lower in other sports such as swimming and athletics, amongst others.

2. Next, we moved on to the analysis of the instrument that was most appropriate to evaluate resilience in elite sports. The CD-RISC resilience scale was selected as the most appropriate as it is the best at adjusting to the circumstances and characteristics of the participant subjects and for its holistic vision of the main factors for a good development of resilience.

3 . The final stage was dedicated to the main core of the study: the adaptation and validation of the instrument to the study population. For its validation, AFC with SEM methodology was applied, adding to the following stages:

3.1. A first stage where the measuring model is specified, which establishes the latent characteristics and dimensions that represent them as variables of interest of a substantive theory.

3.2. Following on, the computerised implementation of a system of structural equations is carried out, which is used to generated the evidence of the validity of the measuring model and its dimensions.

3.3 Subsequently, the goodness of fit indices and criteria are determined, which permit the relating of validating evidence with the dimensional structure of the instrument being evaluated.

3.4. Lastly, the measuring model is again specified with the aim of improving its adjustment, adding or eliminating relationships between factors.

\section{Data Analysis}

The purpose of the AFC is to specify the relevant aspects of the model in advance, which should be previously and strongly grounded in theory and known evidence (Arias, 2008).

It is because of this that the AFC is employed in this study to check whether the factors and indicators that form part of the original Connor-Davidson model (2003) show saturations in each factor, whether or not there are relationships between the factors and with the pre-specified population.

We have carried out an analysis of multiple regression coefficients based on structural equations, based on a criterion of maximum likelihood according to the multivariate normality criteria of items. The values that represent the unidirectional arrows are the lines of influence between the latent and observed variables. They have been calculated using the AMOS 20.2 program, via the analysis of the covariance matrix of the observed variables. The values that appear at the end of the graph are goodness of fit indices for an evaluation of the model (see graph 1). Their application and interpretation is described below.

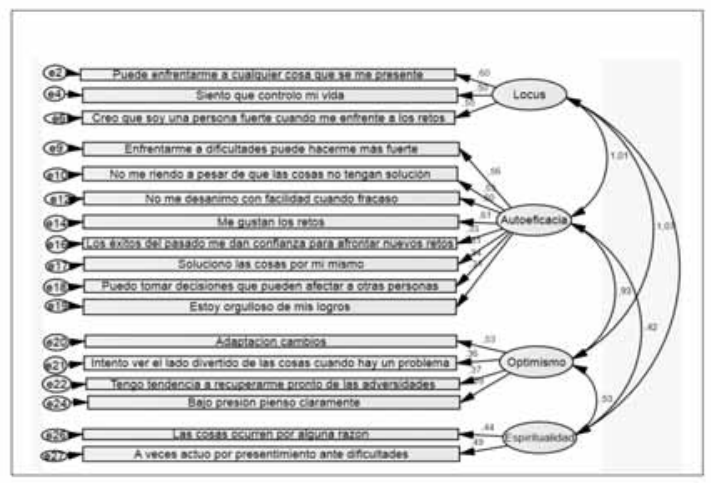

Figure 1. Result of the model in the panth graf
Four dimensions were obtained. Locus dimension, referring to the responsibilities of response that the subject has as a response to adverse situations. It consists of 3 items: 4, 22 and 11.

Self-efficacy dimension, encompassing aspects favourable to a person's strengths, and adaptive responses before situations of risk. It consists of 8 items: 5, 15 and 25.

Optimism dimension, which permits the holding of positive perspectives or attitudes towards circumstances that make us feel vulnerable. It consists of 4 items: 1, 6, 8 and 14 .

Spiritual dimension, which addresses transcendental beliefs that provide strength to confront or understand high-risk moments. It consists of 2 items: 9 and 20.

In total, we have the obtaining of 17 variables of resilience constructed from the 25 variables that comprise the original CD-RISC scale.

Internal consistency of the dimensions of the CD-RISC questionnaire.

The dimensions that make up the adjusted model of the CD-RISC questionnaire adjust to a high level of internal consistency measured via Cronbach's Alpha, standing at 0.717.

\section{Results}

The regression coefficients between latent and observed variables are interpreted in the following manner. The first three values are: $0.60,0.50$ and 0.55 and their correspondence with the influence of the latent variable locus of control and commitment (VAR 1) over the observed variables: p2, p4 and p6.

The influence exerted by the latent variable self-efficacy and resistance to discomfort over the observed variables indicates that when VAR 1 increases 1, p9, p10, p12, p14, p16, p17, p18 and $\mathrm{p} 19$ increase respectively in proportion to the factorial loads $0.56,0.53,0.50,0.61,0.33,0.31,0.34$, and 0.31 . Because all of the observed variable signs are positive, they indicate that as the unit increases the latent variable, the relationship between the latent and the observed variable increases proportionately.

The following four values are: $0.53,0.36,0.37$ and 0.69 and their correspondence to the influence of the latent variable optimism and adaptations to stressful situations (VAR 3) over the observed variables:

And lastly, the following values of 0.44 and 0.49 correspond to the influence of the latent variable spirituality (VAR 4) over the observed variables p26 and p27.

In summary, the results of this stage show that the evaluation of the structural equations model verifies to us that the direction of the derived coefficients has been positive in accordance with the theory employed to configure the measurement model. No inverse relationship has appeared, as we have not obtained negative regression coefficients.

\begin{tabular}{|c|c|c|c|c|c|c|}
\hline MODEL & CMIN & $\mathbf{P}$ & RMSEA & NFI & CFI & TLI \\
\hline $\begin{array}{l}\text { Model } 1 \\
4 \text { Factors } \\
17 \text { Items }\end{array}$ & 136,553 & 0.065 & 0.028 & 0.891 & 0.962 & 0.954 \\
\hline
\end{tabular}

With respect to the application of indices and goodness of fit adjustment criteria between the matrix derived from the data and the matrix reproduced by the model, a difference between the two matrices that has not been statistically significant has been obtained, to which it can be stated that both matrices are close to each other, and therefore that the measurement model and the observed data fit.

With these parameters (17 variables and 4 factors) a model with 113 levels of freedom was defined with maximum legitimacy 
and characterised by $\div 2$ of 136,553 . It stands out that the value of $p$ is greater than 0.05 , which indicates that the difference between the compared covariant matrices (derived and reproduced) is statistically insignificant. This result implies by itself that the model and the data fit. Notwithstanding, other goodness of fit indices are evaluated which confirm the aforementioned result.

The most important goodness of fit index worked with given these results is the Root Mean Square Error of Approximation (RMSEA) (González, \& Backhoff, 2011). The RMSEA value is 0.028 , to which we have an excellent fit. The normed fit index (Bentler \& Bonnet NFi, 1980) is 0.819, and the comparative with respect to the saturated model (CFI de Bentler, 1990) is 0.962, values that are a lot more than optimum. This was also the case for the Tucker \& Lewis index (TLI) (1973), where we obtained a very good fit (0.954), on comparing the fit by degree of freedom from the proposed model and the invalid one. The Alpha Cronbach is acceptable (0.794).

\section{Discussion}

The adaptation of the Conner-Davidson Resilience Scale (CD-RISC) (2003) questionnaire has demonstrated that it has a good factorial structure, good stability and a high internal consistency.

The assessment of the structural equations model verifies to us that the derived coefficients have a positive direction in accordance with the theory.

The exploratory factorial analysis of main components identified a structure in four factors: Locus, Self-efficacy, Optimism and Spirituality, taking in 17 items. The denomination of the factors was carried out seeking the links between the variables with high factorial saturations, which indicate the influence of each variable in the factor.

Previous studies confirm the internal validity and reliability of the CD-RISC scale (Burns \& Anstey, 2009; Campbell- Sills \& Stein, 2007; Coates, Phares \& Dedrick, 2013; Green et al. 2014; Vaishnavi, Connor \& Davidson, 2007).

In each study the CD-RISC scale has been adapted to the characteristics of the subjects and their context, in such a manner that on specific occasions this has had to be reduced in their number of items involved in the development of the factorial and psychometric analyses in a different way for each case.

In reference to our study we found, prior to it, the validation of the CD-RISC in a population of senior citizens, SerranoParra et al. (2013) where they used the structural equations model to obtain the confirmatory factorial analysis before the validation. They obtained results of a CFI of 0.823 against our CFI of 0.962 .

In their study, the factorial solution fitted with $\div 2$ of $2,123.7$ $p=0.001$. Whereas our study presents $\div 2$ of 136,553 where $p$ is greater than 0.05 . This result implies that the model and the data fit between themselves.

With respect to the number of items and their dimensions we find a reduction of the original CD-RISC scale of 25 items to 10 under the 5 original dimensions, compared to our study where we obtained 17 items in 4 dimensions.

Furthermore, we are supported by a study undertaken by Campbell-Sills \& Stein (2007), who analysed the data of two independent samples of university students, deriving a model of four factors that provided a better fit. Our study coincides with the result, as it obtains a model of four factors that allows us to state the obtaining of a clear fit of measurement.

In this study the main limitation comes from the small number of participants and the few sport analysed. Future investigations should try to establish links between genders. In this line, future studies should explore the structure of other athletes of different levels. Secondly, it could be interesting to develop researches in which other variables will be employed (social context, various sports, etc.).

In short, the results obtained show a good reliable fit, which allows it to be a candidate for use in sports environments containing psychological factors or risk situations that alter dynamism in a sports career.

\section{Conclusions}

The CD-RISC is a measurement of self-perception of the capacity for recovery, and includes a good psychometric property. On using the CD-RISC, the results of this study verify that the validation of the instrument is good, and can be extrapolated to any combination of subjects with the field of sports. The participants demonstrated that they knew the resilience construct, to which it allowed us to discover that resilience is becoming an increasingly important factor in new social and psychological environments. This should be taken into account in day to day development, as a behavioural and cognitive support factor when we have to face situations of vulnerability or change.

\section{References}

Almeida, P., Luciano, R., Lameiras, J. \& Buceta, J.M. (2014). Beneficios percibidos de las lesiones deportivas: estudio cualitativo en futbolistas profesionales y semiprofesionales. Revista de Psicología del Deporte, 23 (2), 457- 464.

Anderson, K.M. \& Bang, E.J. (2012). Assessing PTSD and resilience for females who during childhood were exposed to domestic violence. Child \& Family Social Work, 17, 55-65.

Arias, B. (2008). Desarrollo de un ejemplo de anaìlisis factorial confirmatorio con LISREL, AMOS y SAS. Seminario de Actualizacioìn en Investigacioìn sobre Discapacidad SAID. Mimeografiìa no publicada.

Aroian, K. \& Norris, A. (2000). Resilience, stress and depression among Russian inmigrants to Israel. Journal of Nursing Research, 22 (1), 5467.

Bentler, P. M. \& Bonnet, D. C. (1980). Significase Tests and goodness of fit in the analysis of covariance structures. Psychological Bulletin, 88 (3), 588- 606.

Bentler, P. M. (1990). Comparative fit indexes in structural models, Psychological Bulletin, 107 (2), 238- 246.

Bentler, P. M. (2007). Can scientifically useful hypotheses be tested with correlations? American Psychologist, 62, 772- 782.

Bobes, J., Bascarán, M.T., García- Portilla, M. P., Bousa;o, M., Sáiz, P. A., Wallance, D. H. \& Hidalgo, R. B. (2008). Banco de Instrumentos básicos para la práctica de la psiquiatría clínica $\left(5^{a}\right.$ Ed). Barcelona: Ars. Médica.

Burns, R. A. \& Anstey, K. J. (2010). The Connor- Davidson Resilience Scale (CD-RISC). Testing the invariance of a uni-dimensional resilience measure that is independent of positive and negative effect. Personality and Individual Differences, 48 (5), 527- 531.

Campbell- Sills, L. \& Stein, M. B. (2007). Psychometric analysis and refinement of the Connor- Davidson Resilience Scale (CD-RISC): validation of a 10 item measure of resilience. Journal of Traumatic Stress, 20, 1019- 1028.

Cardoso, F.L. \& Sacomori, C. (2014). Resilience of Athletes with physical disabilities: A cross- sectional study. Revista de Psicología del Deporte, 23 (1), 15-22.

Castro Sánchez, M., Chacón Cuberos, R., Zurita Ortega, F. \& Espejo Garcés, T. (2016). Niveles de resiliencia en base a modalidad, nível y lesiones deportivas. Retos, 29, 162-165.

Cevada, T., Silva, L., Sales de Moraes, H., Meireles, T., Monteiro, F. \& Camaz, A. (2012). Relação entre esporte, resiliência, qualidade de vida es ansiedade. Revista psicología clínica, 39 (3), 85-89.

Coates, E. E., Phares, V. \& Dedrick, R.F. (2013). Psychometric properties of the Connor-Davidson Resilience Scale 10 among low-income, African American men. Psychological Assessment, 25 (4), 1349-1354.

Connor, K. M. \& Davidson, J. R. T. (2003). Development of a new resilience scale: the Connor- Davidson Resilience Scale (CD-RISC). Depression and Anxiety, 18, 76- 82.

Chacón Cuberos, R., Castro Sánchez, M., Espejo Garcés, T. \& Zurita 
Ortega, F. (2016). Estudio de la resiliencia en función de la modalidad deportiva: fútbol, balonmano y esquí. Retos, 29, 157- 161.

Da Costa, R. \& Ferreira, M. R. (2013). Resilience in sport: an ecological perspective on human development. Motriz-Revista de Educacao Fisica, 19 (1), 151-159.

Fletcher, D. \& Sarkar, M. (2012). A grounded theory of psychological resilience in Olympic Champions. Psychology of Sport and Exercise, 13 (5), 669- 678.

Forés, A., \& Grané, J. (2012). La resiliencia en entornos socioeducativos. Barcelona: Narcea.

Galli, N, \& Vealey. (2008). 'Bouncing back' from adversity: athletes experiences of resilience. The sport psychologist, 22, 316- 335.

Galli, N. \& González, S.P. (2014). Psychological resilience in sport: A review of the literatura and implications for research and practice. International Journal of Sport and Exercise Psychology, 17, 456-468.

García Secades, X., Salguero del Valle, A., Molinero González, O., De la Vega Marcos, R., Ruíz Barquín, R. and Márquez Rosa, S. (2015). El papel del perfil resiliente y estrategias de afrontamiento sobre el estrésrecuperación del deportista de competición. Kronos, 14(1).

González-Montesinos, P. \& Backhoff, E. (2010). Validación de un cuestionario de contexto para evaluar sistemas educativas con modelos de ecuaciones estructurales. Revista Electrónica de Investigación y Evaluación Educativa, 16 (2), 34-45.

Gucciardi, D. F., Jackson, B., Coulter, T.J. \& Mallett, C. J. (2011). The Connor- Davidson Resilience Scale (CD- RISC): Dimensionality and age- related measurement invariance with Australian cricketers. Psychology of Sport \& Exercise, 12, 423- 433.

Green, K.T., Hayward, L.C., Williams, A.M., Dennis, P.A., Bryan, B.C., Taber, K.H., Davidson, J.R.T., Beckham, J.C. \& Calhoun, P.S. (2014) Examining the factor structure of the Connor-Davidson Resilience Scale (CD-RISC) in a post 9/11 U.S. Military veteran sample. Assessment, 21 (4), 443- 451.

Grotberg, H. (2001). Resilience for today. Gaining strength from adversity. Praeger: London.

Hosseini, S. \& Besharat. M. (2010). Relation of resilience whit sport achievement and mental health in a sample of athletes. Procedia Social and Behavioral Sciences, 5, 633- 638.

Iriarte, M. (1999). Análisis del fracaso durante el proceso de rendimiento deportivo: aplicación de un programa de ordenador inductor de fracas. Revista de Psicología del Deporte, 8 (2), 181- 193.

Ivarsson, A., Johnson, U. \& Podlog, L. (2013). Psychological predictors of injury occurrence: a prospective investigation of professional swedish soccer players. Journal of Sport Rehabilitation, 22, 19-26.

Jeste, D.V., Savia, G.N., Thompson, W.K., Vahia, I.V., Glorioso, D.K., Martin, A.S., Palmer, B.W., Rock, D., Golshan, S., Kraemer, H.C. \& Depp, C.A. (2013). Association between older age and more successful aging: critical role of resilience and depression. American Journal of Psychiatry, 170, 188-196.

Lamond, A. J., Depp, C. A., Allison, M., Langer, R., Reichstadt, J. \& Moore, D. J. (2009). Measurement and predictors of resilience among community- dwelling older women. Journal of Psychiatric Research, 43, 148- 154

Luthar, S. S., Cicchetti, D. \& Becker, B. (2000). The construct of resilience: a critical evaluation and guidelines for future work. Child Development, $71,543-562$

Machida, M., Irwin, B. \& Feltz, D. (2013). Resilience in competitive athletes with spinal cord injury: The role of sport participation. Qualitative Health Research, 23 (8).

Manzano- García, G. \& Ayala, J.C. (2013). Psychometric properties of connor- davidson resilience scale in a spanish simple of entrepreneurs. Psicothema, 25 (2), 245- 251.

Markovitz, S., Peters, M.L., Schrooten, W. \& Schouten, E. (2014). Psychometrische evaluatie van de CD-RISC in een Nederlandstalige populatie: een multi of unifactorieel meetinstrument om veerracht te meten? Tijdschrift Klinische Psychologie, 44 (1), 55-68.

Masten, A. S. \& Powell, J. L. (2003). A resilience framework for research, policy and practice. In S.S. Luthar (Eds.), Resilience and vulnerability: Adaptation in the context of childhood adversities (pp. 1-25). New York: Cambridge University Press.

Masten, A. S. \& O’Dougherty Wright, M. (2010). Resilience over the lifespan. In J. W. Reich, A. J. Zautra, \& J. Stuart-Hall (Eds.), Handbook of adult resilience (pp. 213- 237). New York City, NY: The Guildford Press.

Morgan, P., Fletcher, D. \& Sarkar, M. (2013). Defining and characterizing team resilience in elite sport. Psychology of Sport and Exercise, 14, 549-559.
Olmedilla, A., \& García-Mas, A. (2009). El modelo global psicológico de las lesiones deportivas. Acción Psicológica, 6 (2), 77-91.

Otto, L.M., Howerter, A., Bell, I.R. \& Jackson, N. (2010). Exploring measures of whole person wellness: integrative well-being and psychological flourishing. Explore, 6, 364-370.

Petrie, T. A., Deiters, J. \& Harmison, R. J. (2013). Mental Toughness, Social Support, and Athletic Identity: Moderators of the Life StressInjury Relationship in Collegiate Football Players. Sport, Exercise, and Performance Psychology, 5, 1-15.

Reche, C. \& Ortín, F. (2014). Consistencia de la version española de la escala de resiliencia en esgrima. Avanes de la Psicología del Deporte en Iberoamérica, 2, 49- 57.

Rizopoulos, D. (2006). Ltm: An R Package for Latent Trait Modeling and Item Response Theory Analyses. Journal of Statistical Software, 17 (5).

Romero Barquero, C. E. (2015). Meta- análisis del efecto de la actividad física en el desarrollo de la resiliencia. Retos, 28, 98- 103.

Ruíz, R., De la Vega, R., Poveda, J., Rosado, A., and Serpa, S. (2012). Análisis psicométrico de la Escala de resiliencia en el deporte del fútbol. Revista Psicología del deporte, 2 (1), 143- 151.

Ruíz - Barquín, R., Del Campo Vecino, J. \& De la Vega Marcos, R. (2015). La resiliencia en entrenadores de atletismo de alto rendimiento. Revista Iberoamericana de Psicología del Ejercicio y del Deporte, 10(1), 69-75.

Sarkar, M. \& Fletcher, D. (2014). Psychological resilience in sport performers: a review of stressors and protective factors. Journal of sports sciences, 32 (15), 1419- 1434.

Serrano- Parra, M. D., Garrido-Abejar, M., Notario- Pacheco, B., BartoloméGutíerrez, R., Solera- Martínez, M. \& Martínez- Vizcaíno, V. (2013). Validity of the Connor- Davidson resilience scale (10 items) in a population of elderly. Enfermeria Clínica, 23 (1), 14-21.

Solano, J.P.C. \& Neto, L. (2012). Cross-cultural adaptation and validation of Brazilian Portuguese versions of the dispositional resilience scale and Connor-Davidson resilience scale. World Psychiatric Association, Section on Epidemiology and Public Health, 10 (3), 44-46.

Trip, D. A., Stanish, W., Ebel- Lam, A., Brewe, B. W. \& Birchard, J. (2011). Fear of reinjury, negative affect, and catastrophizing predicting return to sport in recreational athletes with cruciat ligament injuries at 1 year postsurgery. Sport, Exercise, and Performance Psychology, 1 (Supl.), 38- 48.

Vaishnavi, S., Connor, K. \& Davidson, J. (2007). An abbreviated version of the Connor- Davidson Resilience Scale (CD- RISC), the CD- RISC 2: psychometric properties and application in psychopharmacological trials. Psychiatry Research, 152 (2, 3), 293- 297.

Wagnild, G. \& Young, H. (1993). Development and psychometric evaluation of the resilience scale. Journal of nursing psychology, 21 (3), 276292.

Wiese- Bjornstal, D. M., Smith, A. M., Schaffer, S. M. \& Morrey, M. A. (1998). An integrated Model of Response to Sport Injury: Psychological and Sociological Dynamics. Journal of Applied Sport Psychology, 10, 46- 69.

Xiaonan, Y., Joseph, T. F., Winnie, W.S., Jianxin, Z. \& Wacy, L. (2011). Factor structure and psychometric properties of the Connor- Davidson Resilience Scale among chinese adolescents. Comprehensive Psychiatry, 52 (2), 218- 224.

Xiaonan, Y. \& Zhang, J. (2007). Factor analysis and psychometric evaluation of the Connor- Davidson Resilience Scale (CD- RISC) with chinese people. Social Behaviour and Personality, 35 (1), 19- 30.

Yi, J., Smith, R. \& Vitaliano, P. (2005). Stress- resilience, illness and coping: a person- focused investigation of young women athletes. Journal of Behavioral Medicine, 28 (3), 257- 265.

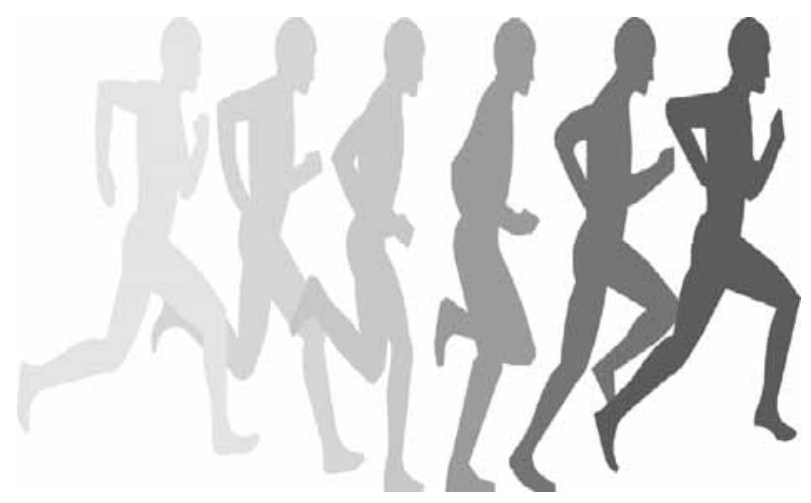

